\title{
An assessment of the relationship between public debt, government expenditure and revenue in Namibia
}

HAMBELELENI IIYAMBO, MBA Finance*

TERESIA KAULIHOWA, PhD*

Article**

JEL: E62, H39, H50, H60

https://doi.org/10.3326/pse.44.3.3

\footnotetext{
* The authors want to thank the anonymous reviewers for insightful comments and suggestions.

${ }^{* *}$ Received: October 1, 2019

Accepted: February 18, 2020
}

\section{Hambeleleni IIYAMBO}

University of Namibia, P.O. Box 13301, Windhoek, Namibia

e-mail: htyambo@gmail.com

ORCiD: 0000-0002-1983-7447

Teresia KAULIHOWA

Namibia University of Science and Technology, P.O Box 13388, Windhoek, Namibia

e-mail: kaulihowat@gmail.com

ORCiD: 0000-0003-1148-4525 
Abstract

This paper investigates the relationship between government expenditure, government revenue and public debt in Namibia by employing the data of these variables for the period 1980 to 2018. An error correction model (ECM) was employed to analyse the short- run dynamics and a positive relationship between government expenditure and government revenue was found. Similarly, there is supporting evidence that an increase in public debt will stimulate government expenditure. The error correction term indicates that any disequilibrium is corrected at an annual speed of 46.4 percent. Additionally, the pair-wise Granger causality test fails to support the spend-revenue hypothesis. However, there is supporting evidence that the tax-spend hypothesis does hold for Namibia. The study recommends that policy-makers should thoroughly review government expenditure and bring it to optimal levels in order to prevent the widening of public debt.

Keywords: public debt, government expenditure government revenue, Namibia

\section{INTRODUCTION}

The future course of fiscal policy, the need to keep government debt under control and the sustainability of public finances have constituted one of the most widely discussed topics in economics (Neck and Sturm, 2008). Moreover, the global crisis and the expansionary government reactions in many countries have revamped the attention of policy-makers and academics to the growth effects of large public debts and budget deficits (Presbitero, 2010) and accordingly fiscal policy sustainability and public debt remain a concern to any economy, whether developed or developing. The Namibia government budget mainly consists of government expenditures and government revenues. Total government revenues refer to all tax and non-tax revenues collected by governments including grants, while total government expenditures are all operational and development expenditures incurred by the government in a particular financial period (Ministry of Finance (MOF), 2017). Imbalances between government expenditures and revenues will translate into a budget deficit or surplus.

Labonte (2012), Cottarelli and Schaechter (2010) argue that reduced budget deficits may in the short run result in increased unemployment, while persistent accumulation of public debt beyond levels deemed sustainable will cause difficulties in adjusting fiscal variables especially through their effects on gross domestic product (GDP). Since independence, Namibia has made efforts to maintain fiscal prudence with the objective of attaining overall macro-economic stability and laying the foundations for sustainable economic development (MOF, 2005). However, the continuing high incidence of unemployment and poverty has required significant levels of spending on social and economic development programmes, which has resulted in expenditure exceeding revenue and subsequently in budget deficits and build-ups of debt (MOF, 2005). Like other developing countries, such as Nigeria, that have relied substantially on debt to finance most of their expenditures (Oladokun, 2015), Namibia has experienced persistent budget deficits and increasing 
borrowing requirements resulting from both operational and developmental overexpenditure. The accumulation of public debt has raised concerns about the longterm sustainability of government operations. The further implication is that the reliance on revenue alone has been inadequate to finance government expenditure in Namibia, indicating the importance of both government revenue and public debt as determinants of public expenditure. In examining the relationship between public debt, government expenditure and revenue, it is important to understand the major trends and outcomes of the economy through time as they have various implications for the interactions between these variables.

\section{Figure 1}

The composition of government revenue, government expenditure and public debt in Namibia 1990-2016 (in billion N\$)

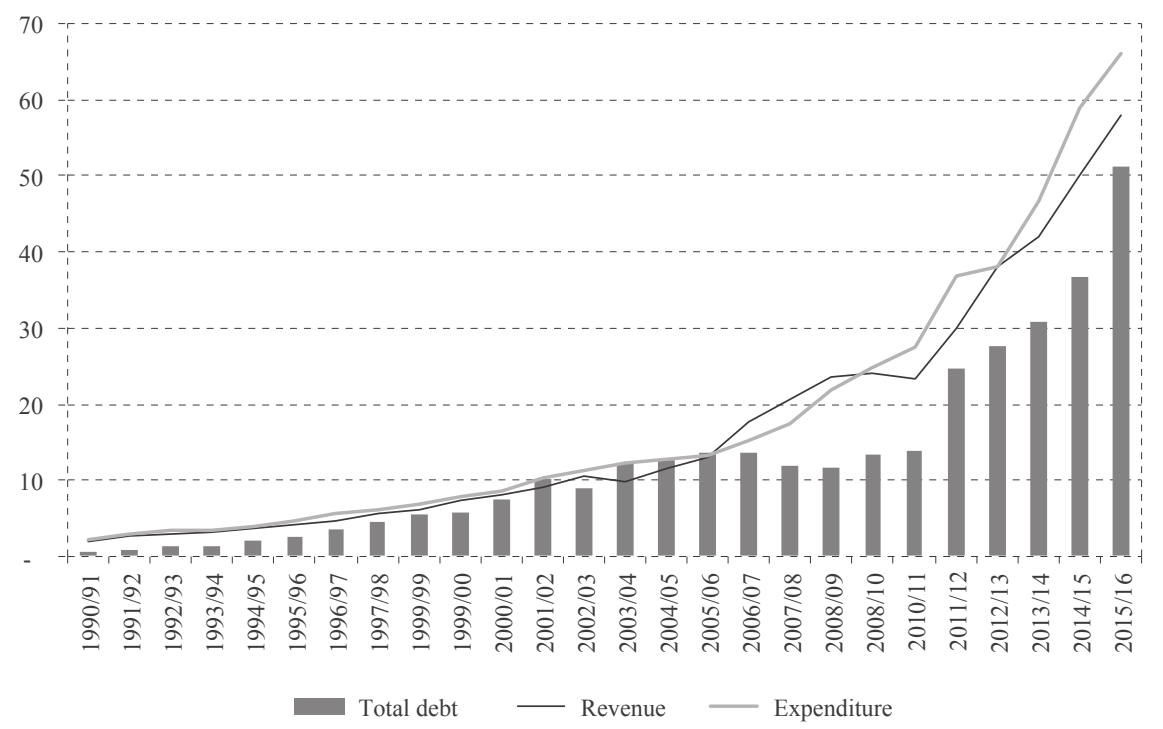

Source: Authors.

In Figure 1, a stable total debt is observed between the years 2006-2010, due to the high reliance on revenue alone to finance expenditure. Also, during the same period, the Namibian government found it essential to formulate its first sovereign debt management strategy (SDMS) in 2005 with the objective of minimising the cost of government borrowing and ensuring that sovereign debt remains affordable and low in risk in the future. Consequently, a medium term expenditure framework (MTEF) was introduced, to encourage fiscal discipline and limit additional borrowing needs. The increase in total revenues was due to the improved revenue thresholds. However, a reduction during the 2010/2011 financial year was due to a decrease in the Southern African Customs Union (SACU) revenues (Sherbourne, Nampila and du Preez, 2002). 


\section{Figure 2}

The composition of public debt, government expenditure and revenue in Namibia 1990-2016 (as \% of GDP)

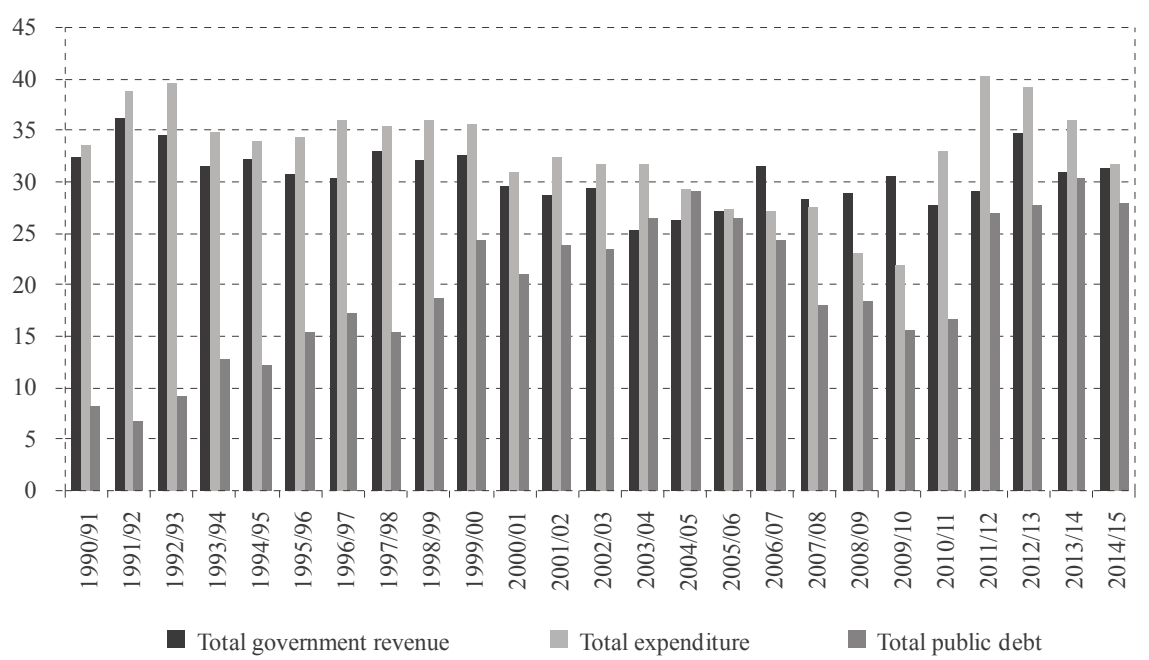

Source: Authors.

In Figure 2, it is evident that, even after the implementation of the SDMS and MTEF, the fiscal variables have been on the rise. As a result, fiscal sustainability has become an important aspect for any government, including Namibia. According to Zaaruka, Ndove and Tjipe (2004), fiscal sustainability is achieved when the expenditure for which debt has been incurred positively contributes to GDP growth, subsequently inducing an equivalent increase in government revenue to service the debt. Furthermore, fiscal sustainability is more about the urgency of policy changes and the need for new budget tools to assess governments' fiscal position than merely projecting the future (Schick, 2005). However, from the above and as supported by Balassone and Franco (2000), there is no defined unique benchmark against which to assess sustainability. Through Domar's framework, Balassone and Franco (2000) further argue that sustainability requires that the debt to GDP ratio is stable, while not any stable level is necessarily sustainable. And therefore, the interaction of public finance and the economy should be considered to assess the maximum sustainable debt level.

The increase in the country's debt raises doubts about whether the Namibian government's current fiscal policies are sustainable. As asserted by Zaaruka, Ndove and Tjipe (2004), Namibia has been experiencing an increasing level of government debt and persistent budget deficits since independence, which has raised concerns regarding the sustainability of fiscal policy in Namibia. According, to the literature, countries have adopted benchmarks for government expenditure, budget deficits and public debts to be within $40 \%, 5 \%$ and $35 \%$ of GDP, respectively (MOF, 2017). Despite the government's efforts to introduce the SDMS and the MTEF, Namibia has breached its own thresholds. The total expenditure, 
budget deficit and public debt exceeded the targets by end of 2015/2016 while total government revenue slowed to $35 \%$, failing to keep up with growing public spending (MOF, 2017).

To achieve fiscal sustainability, it is necessary to understand the relationship between public debt, government expenditure and revenue to obtain an insight into whether government spending leads to public debt and revenues, or whether public debts and revenue are the drivers of spending in Namibia. To our knowledge, there is currently limited research in Namibia intended to address the relationship between public debt, government expenditure and revenue. In view of the rising concerns about fiscal sustainability and the increase in debt burdens, expenditure and budget deficits above their thresholds in Namibia, it is imperative to examine and understand the underlying dynamics.

This research is aimed at addressing both the literature gap and policy-makers' concerns about fiscal sustainability by investigating the relationship between government expenditure, revenue and public debt in Namibia over the period from 1980 to 2018. To achieve this, the specific objectives of the paper are to examine the relationship between government expenditure and public debt, analyse the relationship between government expenditure and government revenue and determine the direction of causality between government expenditure and public debt as well as the direction of causality between government expenditure and government revenue.

This paper contributes to the empirical literature in three ways. Firstly, the paper will enhance understanding of government finance in small developing open economies. Secondly, the paper will further serve as an insight to help policymakers in Namibia to improve both fiscal and debt management strategies to enhance fiscal sustainability and maintainable debt levels. Thirdly, the paper will add value and broaden the area of research in public debt, government expenditure and revenue and significantly benefit other researchers and scholars as a basis for further research and source of reference.

The paper is structured into five sections. This section gave a brief background on the area of the study in the context of the Namibian economy. The next session presents both the relevant theoretical and empirical literatures, section three presents the research methodology employed while section four presents the empirical results and interpretations. Conclusions and policy recommendations of the study are reported in the last section.

\section{LITERATURE REVIEW}

\subsection{THEORETICAL LITERATURE}

Public debt, government expenditure and government revenue are important areas of study in the field of public finance and economic policy and as such have gained momentum over time. Proponents of the tax smoothing theory assume that taxes are distorting to the economy due to their effect on labour supply which the 
government minimises by allocating taxes across time (Barro, 1979). Through this theory, any increase in government spending will cause governments to run budget deficits and resort to borrowing in order for them to maintain constant tax rates over time. The positive theory of public expenditure or the displacement effect argues that government expenditures do not increase continuously but rather in a displacement manner. A period of social disturbances requires an increase in government expenditures, which current revenues are unable to meet. As a result, public expenditure is displaced from the old level, resulting in tax rates also increasing in order to sustain the increasing defensive expenditure which never returns to the old level, leading to public debt accumulation. This further assumes a positive relationship between the three variables, confirming the spend-tax hypothesis (Peacock and Wiseman, 1961).

The spend-tax hypothesis through the displacement further received support from the Ricardian equivalence theory of Barro (1974). The theory mainly states that the use of public borrowing or the raising of taxes to meet budget deficits does not really matter. The same positive relationship between government expenditure and government revenue is expected as between government expenditure and public debt. Barro (1974) argues that taxation and public borrowing constitute essentially equivalent forms of financing public expenditures. The government is expected at some future time to redeem its debt which will usually occur through increased future taxation.

Set against the spend-revenue hypothesis is the revenue-spend hypothesis of Friedman (1978) and Buchanan and Wagner (1977). According to this theory, governments will first collect the money raised from taxes before spending it on government operations assuming an unidirectional causality running from government revenue to government expenditure. According to Friedman (1978), any tax increases will cause an increase in expenditures, only because governments are unable to reduce budget deficits. Similarly, Buchanan and Wagner (1977) argue that a decrease in taxes will cause government expenditures to increase due to the fiscal illusion that results from public perceptions of reduced government activities. These perceptions allow the general public to demand more from the government, increasing government expenditures and budget deficits.

Another contribution to theories on the fiscal variables is Lerner's theory of functional finance, mainly by Lerner (1943), which is based on the principle of judging fiscal measures based on their function in the economy, called functional finance. This theory suggests that the government should keep the spending rate on expenditure (aggregate demand) within the rate of aggregate supply to avoid inflation or unemployment. To ensure that the required total spending level is achieved, the government can implement either an expansionary or a restrictive fiscal policy.

Opposing public debt is the classical theory of public debt drawn from the theoretical concept of laissez-faire, which is also known as the free-market theory. This 
theory is championed by the classical economists who shared a common principle with regards to public debt, expenditure and revenue, namely Adam Smith and John Stuart Mill. Smith (1937) in The Wealth of Nations argues that the accumulation of debt due to budget deficits is to be considered pernicious for the nation even if all of it is owed to domestic investors, and should therefore be avoided. This is supported by Mill (1979) in his Principles, arguing, however, that public debt might not be pernicious to a country if financed from foreign savings. This means that there is no crowding out effect when government borrowings absorb domestic savings that would either be invested unproductively or invested in foreign countries.

Contrary to the classical theory is the Keynesian theory on public debt by John Maynard Keynes. Keynes (1936) concurs that the growth of any economy can be stimulated by increased government expenditures and lower taxes; and that governments use fiscal policies in times of recession to improve economic activities. However, governments would cut taxes and increase expenditure to stimulate aggregate demand in times of depression. The above theories all have conflicting views in an attempt to confirm the relationship between government revenue, expenditure and public debt. Some theories assume that causality runs from revenue to spending, while others urge that government spending increases or decreases government revenue.

From the above, the Keynesian theory on public debt is expected to be one of the most interesting for a developing economy such as Namibia. This is because the government may use fiscal policies in times of recession to improve economic activities. The positive relationship expected between the variables can be further related to the positive theory of public expenditure or displacement effect as the increase in government expenditure in a developing economy may lead to insufficient existing levels of revenue, causing public debt accumulation. Lastly, in terms of causality, the revenue-spend hypothesis by Friedman (1978) is most plausible in our developing economy due to the high reliance of expenditure budgets on revenue collection.

\subsection{EMPIRICAL LITERATURE}

Empirical literature on the relationship between public debt, government expenditure and revenue is not without ambiguities. The positive relationship between public expenditure and public debt has been reported by Kiminyei (2014); Uguru (2016); Idenyi, Ogonna and Ifeyinwa (2016); Alawneh (2017); Mah et al. (2013). Kiminyei (2014), focused on the response of public debt to tax revenue and government expenditure in Kenya over 1960 to 2012. The study used the vector error correction model with correlation analysis as the data analysis tool. The study found a significant positive long run relationship between public debt and both tax revenue and government expenditure. Similarly, Uguru (2016) explored the relationship between public debt and government expenditure in Nigeria from 1980 to 2013 where a positive relationship between government expenditure and public debt is reported. This finding is consistent with Alawneh (2017) who examined 
the impact of total government expenditure and total public debt on taxes in Jordan during the period 2001 to 2014. Although the results are in line with the theory of public expenditure, it did not establish the direction of causality. Mah et al. (2013) alternatively attempted to determine the impact of government expenditures and government income on government debt in Greece from 1976 to 2011 through the vector error correction model framework. Similarly to the study of Alawneh (2017) and Uguru (2016), the study also discovered a significant positive relationship between gross government debt and gross national expenditure but a negative relationship between gross government debt and gross national income, with causality running from gross national government expenditure and gross national income to government debt.

Conversely, Elyasi and Rahimi (2012) confirmed both the revenue-spend and spend-revenue hypotheses in Iran while Eita and Mbazima (2008) investigated the causal relationship between government revenue and government expenditure in Namibia using the Granger causality test through cointegrated vector auto regression methods for the period 1977 to 2007. Unidirectional causality from government revenue to government expenditure was found, resulting in a revenue-spend hypothesis for Namibia. Similarly, Ogujiuba and Abraham (2012) also found causality running from revenue to expenditure. Another study, this time in Nigeria, revealed contradictory results. Abdulrasheed (2017) established the existence of causality between government expenditure and government revenue with an analysis of an updated annual time series from 1986 to 2015. Cointegration statistical method tests also revealed the existence of long-run equilibrium relationships between government revenue and expenditure variables. Saungweme (2013) also found opposing results in a Zimbabwean government study over the period from 1975 to 2004. Using both bivariate and multivariate Granger causality models to test the tax-spend hypothesis, government expenditure was found to cause revenue. To tackle the problem of the fiscal deficit burden in Serbia, Luković and Grbić (2014) studied the causal relationship between government revenue and government expenditure using quarterly data from 2003 to 2012. The Toda-Yamamoto long-run non-causality method was used and the study findings also confirmed that government expenditure Granger-causes government revenue.

Oladokun (2015) empirically examined the causal relationship between public expenditure and national debt using time series data from 1981 to 2012. The Granger causality test revealed that public expenditure causes domestic debt. Okafor and Eiya (2011) aimed to ascertain the determinants of government expenditure growth through the OLS regression method from 1999 to 2008 in Nigeria. The data revealed a positive relationship between public debt and government expenditure and revenue. Ukwueze (2015) also studied the determinants of government expenditures in from 1961 to 2012 in Nigeria by employing the short-run ECM, the long-run static equation and the OLS estimation technique. The study found that the size of revenue significantly influenced the size of public expenditure, both in the short and the long run. Total debts significantly influenced 
the size of government expenditure only in the short run. Both studies by Ukwueze (2015) and Okafor and Eiya (2011) are in line with the Ricardian equivalence theory implying that both taxes and borrowings constitute essential equivalent forms of financing public expenditures in Nigeria. Kanano (2006) on the other hand also examined the determinants of public expenditure growth in Kenya using the time series data analysis technique for the period 1980 to 2004 through the OLS estimation method. The findings indicated a positive relationship between internal debt and public expenditure, a negative relationship between external debt financing and public expenditure and a strong positive relationship between government revenue and public expenditure. In contrast, Achieng (2012) carried out a study to determine the relationship between budget deficit and domestic debt for twenty years from 1991 to 2010 in Kenya using the multiple regression analysis. A positive relationship between the budget deficit, government expenditure, government revenue and domestic debt was found. Although the study's methodology differed from that of Kiminyei (2014) and Kanano (2006), also in Kenya, the findings are similar. The importance of sustainability further led Elyasi and Rahimi (2012) to determine the causal relationship between government revenue and government expenditure over the period of 1963 to 2007. The results showed a bidirectional causal relationship between government expenditure and revenues in both the long and the short run, confirming the presence of both the revenuespend and spend-revenue hypotheses in Iran. Sutherland (1997) in an attempt to determine the effect of public debt on fiscal policy found that the fiscal policy has the traditional Keynesian effects at moderate debt levels but was detrimental when debt reaches extreme values. This finding is consistent with Ighodaro and Oriakhi (2010) where the Keynesian theory is supported for Nigeria. Similarly to the theories reviewed above, studies that attempted to confirm the relationship between government revenue, expenditure and public debt have conflicting views. From the above empirical findings, the relationships between the variables remain uncertain making it difficult to generalise such relationships to Namibia. Although there have been numerous studies on the individual research variables, studies on the relationship between public debt, government expenditure and revenue remain limited globally, and most especially in Namibia. Also, most of the studies either focused on the relationship of domestic or external debt alone and on tax revenue, instead of on total government revenue. Overall, most studies mainly focused on establishing the relationship between government expenditure and revenue. As a result, this study tends to differ through its attempt to establish the relationship between the total government expenditure, total government revenue and total public debt, making it one of the very few studies in Namibia.

\section{METHODOLOGY}

\subsection{RESEARCH DESIGN}

The study employed a quantitative research design, that of a time series analysis. The approach is appropriate as it enabled the researchers to quantify the relationship between the government expenditure, revenue and public debt through a multiple regression analysis and causality testing. 


\subsection{MODEL SPECIFICATION}

The study adapted a multiple linear regression method similar to that of Abdulrasheed (2017) with public debt as an additional variable. This is in line with Favero and Giavazzi (2007), who emphasised the importance of public debt in policy analyses. The reliance on revenue alone being inadequate to finance government expenditure also favoured the inclusion of public debt. Further, public debt was included due to its effect on government expenditure through interest payments, debt servicing and repayments.

The basic model of this study is presented as follow:

$$
G V T E X_{t}=f\left(P D_{t}, G V T R V_{t}\right)
$$

Where: GVTEX = Nominal government expenditure (total operational and development expenditure); PD = Nominal total public debt (domestic and external debt) and GVTRV= Total nominal government revenue (tax revenue, non-tax revenue and grants).

To solve the problem of autocorrelation, the raw data was transformed into logarithmic forms, where lagged independent variables are used to address endogeneity issues. The multiple regression model, expressed in natural logarithms to determine the relationship between the variables, is as follows:

$$
\operatorname{LnGVTEX} X_{t}=\alpha+\operatorname{LnGVTEX}_{t-1}+\beta_{1} \operatorname{LnPD}_{t-1}+\beta_{2} \operatorname{LnGVTRV_{t}}+\varepsilon_{t}
$$

In the above model, LnGVTEX is the dependent variable whereas LnPD and LnGVTRV are the independent variables. $\beta_{1} \& \beta_{2}$ are regression parameters, $\alpha$ is the constant while $\varepsilon$ is the stochastic error term. Each $\beta$ indicates how, on average, a one percent change in the independent variable affects the dependent variable. From the above, a positive relationship is expected between the government expenditure and public debt as well as between government expenditure and government revenue.

\subsection{DATA SOURCES}

The study sourced the government financial operations actual data on public debt, government expenditure and revenue for the period of 1990 to 2016 from the MOF annual budget reports. The study refrained from using the original source of data as all data pertaining to the study variables were readily available over the same fiscal periods.

\subsection{ESTIMATION TECHNIQUES}

The empirical estimation of the parameters was done within a framework of classical linear regression model (CLRM) using the OLS technique. A descriptive statistics analysis is firstly performed to describe the nature of the time series data. Time series properties (unit root and cointegration) of the data were further 
examined to determine the best fitting model. Granger causality was employed to examine the direction of causality between public debt, government revenue and government expenditure. The E-views statistical software package was used to analyse the data and estimate the regression.

\subsubsection{STATIONARITY TEST}

A time series data is said to be stationary if the mean and variance are constant through time (Gujarati, 2004). In order to avoid spurious result problems, a stationarity test to check the existence of a unit root was firstly examined. The study made use of the Augmented Dickey-Fuller (ADF) test and Phillips-Perron (PP) procedures in testing for unit roots. The null hypothesis that the series are nonstationary (i.e. have a unit root) was tested against the alternative hypothesis.

\subsubsection{COINTEGRATION TEST}

Once the unit root tests results confirmed the non-stationarity of variables at levels, cointegration analysis was considered, which implies the existence of longrun equilibrium relationship among the variables that have been incorporated in a model (Gujarati, 2004). The two tests used are the Engle and Granger and Johansen cointegration tests.

\subsubsection{Johansen and Engle and Granger cointegration}

The trace and maximum eigen value Johansen tests were used. The null hypothesis is rejected if the probability value (p-value) under both trace and maximum eigenvalue tests are less than 5\% (0.05) significance level and the statistics for both tests are greater than the critical value at $5 \%$ level of significance, concluding that the variables are cointegrated. The optimal lag length was also determined based on the model with the lowest Akaike Information Criterion (AIC) or Schwarz Information Criterion (SC) values.

\subsubsection{Engle and Granger cointegration}

Cointegration is also confirmed by testing the stationarity of the residuals from the cointegration regression (Engle and Granger, 1987). Therefore, the residuals (Ut) obtained from OLS multiple regression between LnGVTEX, LnPD and LnGVTRV (equation 2) are saved and further tested through the ADF tests for a unit root.

\subsubsection{ERROR CORRECTION MODEL}

Based on the cointegration property, the ECM is estimated. The short-run ECM to estimate the speed at which the disequilibrium in the model is corrected was specified, indicating the changes in the dependent variable as a function of the disequilibrium error and the changes in the independent variables. The error correction model is specified below:

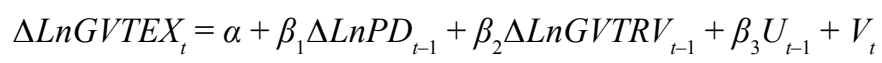


Where $\alpha$ is the constant, $\Delta$ LnGVTEX, $\Delta \mathrm{LnPD}$ and $\Delta$ LnGVTRV are the differenced log variables for government expenditure, public debt and government revenue respectively. $\beta_{1}$ and $\beta_{2}$ are the short-run coefficients, while $U_{t-1}$ is the one period lagged residual of equation 2. The coefficient of the $U_{t-1}$ in this case $\beta_{3}$, measures the speed or rate at which the ECT adjusts the previous period disequilibrium and the sign of the residual lag must be negative and significant to indicate a long-run equilibrium relationship. The greater the coefficient of the ECT, the faster the speed of adjustment of the model from the short run to the long run (Granger, 1969). The $V_{t}$ is the white noise error term.

\subsubsection{GRANGER CAUSALITY}

The Granger causality test is a technique for determining whether one time series is significant in forecasting another (Ray, 2012). Granger (1969) is of the opinion that $\mathrm{Y}$ "Granger causes" $\mathrm{X}$ if $\mathrm{X}$ is only best predicted by using the lag values of $\mathrm{Y}$ on assumptions that the future cannot cause the past, but the past can cause the present or the future; and that a cause contains unique information about an effect not available anywhere else. Based on the above, the study employs the pair-wise Granger causality test as proposed by Granger (1969) to test the causal relationship between variables. The test determines whether the causality runs from GVTEX to PD or rather from PD to GVTEX, implying a unidirectional causality; whether both the PD and GVTEX simultaneously Granger cause each other, implying a bidirectional causality; or whether causality between PD and GVTEX is non-existent. Similarly, the test also determines whether the causality runs from GVTRV to GVTEX, or rather from GVTEX to GVREV; or if both GVTEX and GVTRV mutually cause each other and lastly; whether there is no causality between GVTEX and GVTRV.

A simple Granger causality test involving the variables, government expenditure and public debt is written in equations 4 and 5 , while that involving govern ment expenditure and government revenue is written in equation 6 and 7 as:

$$
\begin{gathered}
\operatorname{LnPD}_{t}=\sum_{i=1}^{n} \lambda_{i} \operatorname{LnPD}_{t-i}+\sum_{j=0}^{n} \delta_{j} \operatorname{Ln} G V T E X_{t-j}+\varepsilon_{1 t} \\
\operatorname{LnGVTEX}_{t}=\sum_{i=0}^{n} \alpha_{i} \operatorname{LnPD}_{t-i}+\sum_{j=1}^{n} \beta_{j} \operatorname{LnGVTEX}_{t-j}+\varepsilon_{2 t} \\
\operatorname{LnGVTRV}_{t}=\sum_{i=1}^{n} \varphi_{i} \operatorname{LnGVTRV_{t-i}}+\sum_{j=0}^{n} \gamma_{j} \operatorname{LnGVTEX}_{t-j}+\varepsilon_{1 t} \\
\operatorname{LnGVTEX}_{t}=\sum_{i=0}^{n} \psi_{i} \operatorname{LnGVTRV}_{t-i}+\sum_{j=1}^{n} \rho_{j} \operatorname{LnGVTEX}_{t-j}+\varepsilon_{2 t}
\end{gathered}
$$

where LnGVTEX refers to government expenditure and LnPD and LnGVTRV refer to public debt and government revenue respectively. Also, $\varepsilon_{1 t}$ and $\varepsilon_{2 t}$ are the 
stochastic error terms that are not correlated with each other; and $\alpha_{i}, \beta_{j}, \lambda_{i}, \delta_{j}$ are the coefficients of the variables. From the above equations, the null hypotheses to

be tested are then $\mathrm{H}_{0}: \sum_{\mathrm{i}=1}^{\mathrm{n}} \alpha_{\mathrm{i}}=0$ for $\mathrm{i}=1 \ldots \mathrm{n}$, which implies that LnPD does not Granger cause LnGVTEX and that LnGVTRV does not Granger cause LnGVTEX; and $\sum_{\mathrm{j}=1}^{\mathrm{n}} \delta_{\mathrm{j}}=0$ for $\mathrm{j}=1 \ldots \mathrm{n}$, implying that LnGVTEX does not Granger cause LnPD and that LnGVTEX does not Granger cause LnGVTRV. If none of the hypotheses are rejected, it means that LnPD does not Granger cause LnGVTEX nor does LnGVTEX Granger cause LnPD. Rejecting the first hypothesis while accepting the second hypothesis shows that LnPD Granger causes LnGVTEX, but LnGVTEX does not Granger cause LnPD. Similarly, accepting the first hypothesis while rejecting the second hypothesis indicates that the causality runs from LnGVTEX to LnPD. Lastly, if all the hypotheses in the above equations are simultaneously rejected, there is bidirectional causality between the two variables. The above interpretations will apply with regards to causality between government expenditure and government revenue.

\subsubsection{DIAGNOSTIC TESTS}

The heteroscedasticity test was performed under the decision criteria of rejecting the null hypothesis of no heteroscedasticity, if the calculated F-statistic is greater than the critical F-statistic. The autocorrelation test, which tests for the inconsistency of the error term used the Breusch-Godfrey serial correlation LM test to test the null hypothesis that there is no serial correlation. To ensure that the model used in the study is normally distributed, the null hypothesis of normality was tested against the alternative. A stability test to ensure the model's suitability for analysis was also confirmed.

\section{EMPIRICAL RESULTS AND DISCUSSIONS}

\subsection{DESCRIPTIVE STATISTICS}

Table 1 shows the series descriptive statistics. The descriptive statistics were performed on the raw data before log form transformation. Overall, government expenditure remains higher in magnitude than the rest of the variables, implying that the Namibia government has been experiencing a budget deficit over the years, while public debt remains lower than the other variables throughout the years. The standard deviations indicating how far the observations are from the sample mean are below their respective means for all the variables, implying a lower variance. 
TABLE 1

Descriptive statistics

GVTEX

\begin{tabular}{|c|c|c|c|}
\hline Mean & $18,034.03$ & $16,583.59$ & $12,638.15$ \\
\hline Median & $11,821.95$ & $10,164.85$ & $10,905.09$ \\
\hline Maximum & $65,996.03$ & $57,844.84$ & $51,212.00$ \\
\hline Minimum & $2,104.40$ & $2,031.70$ & 501.00 \\
\hline Std. Dev. & $17,659.53$ & $15,568.84$ & $12,367.06$ \\
\hline Skewness & 1.41 & 1.24 & 1.54 \\
\hline Kurtosis & 4.02 & 3.58 & 5.06 \\
\hline Jarque-Bera & 9.78 & 7.12 & 14.98 \\
\hline Probability & 0.01 & 0.02 & 0.00 \\
\hline Sum & $468,884.80$ & $431,173.40$ & $328,592.00$ \\
\hline Observations & 37 & 37 & 37 \\
\hline
\end{tabular}

Source: Authors' compilation.

\subsection{STATIONARITY TESTING}

The time series were tested at levels and at first differencing. A variable is said to be integrated of order one, or I (1), if it is stationary after differencing it once, or order two, I (2) if differenced twice. If the variable is stationary without differencing, then it is integrated of order zero, I (0). When the probability value (p-value) is less that the $5 \%(0.05)$ level of significance, the null hypothesis that there exists a unit root is rejected and vice versa. Moreover, when ADF and PP t-statistics are greater than the t-critical values, the null hypothesis is rejected. The unit root test results for the log forms of public debt, government expenditure and government revenue for the ADF and PP at levels are presented in Tables 2 whereas Table 3 depicts the ADF and PP test at first differencing.

\section{TABLE 2}

Unit root test results at levels- $A D F$ and $P P$

\begin{tabular}{|c|c|c|c|c|c|c|c|}
\hline \multirow{2}{*}{$\begin{array}{l}\text { Vari- } \\
\text { ables }\end{array}$} & \multirow{2}{*}{$\begin{array}{l}\text { Determinis- } \\
\text { tic terms }\end{array}$} & \multicolumn{3}{|c|}{ ADF - levels } & \multicolumn{3}{|c|}{ PP- levels } \\
\hline & & $\begin{array}{l}\text { t-statis- } \\
\text { tic }\end{array}$ & $\begin{array}{c}\text { t-critical } \\
\text { values } \\
5 \%\end{array}$ & P-values & $\begin{array}{c}\text { t-statis- } \\
\text { tic }\end{array}$ & $\begin{array}{c}\text { t-critical } \\
\text { values } \\
5 \%\end{array}$ & P-values \\
\hline \multirow[b]{2}{*}{ LNPD } & Intercept & -2.3399 & -2.9862 & 0.1681 & -2.3899 & -2.9862 & 0.1544 \\
\hline & $\begin{array}{l}\text { Intercept and } \\
\text { constant }\end{array}$ & -2.7871 & -3.6032 & 0.2143 & -2.7673 & -3.6032 & 0.2210 \\
\hline \multirow{2}{*}{$\begin{array}{l}\text { LNGV- } \\
\text { TEX }\end{array}$} & Intercept & -0.0541 & $\begin{array}{l}-2.9862 \\
\end{array}$ & 0.9443 & -0.0277 & $\begin{array}{l}-2.9862 \\
\end{array}$ & 0.9472 \\
\hline & $\begin{array}{l}\text { Intercept and } \\
\text { constant }\end{array}$ & -1.9387 & -3.6032 & 0.6048 & -2.0739 & -3.6032 & 0.5345 \\
\hline \multirow{2}{*}{$\begin{array}{l}\text { LNG- } \\
\text { VTRV }\end{array}$} & Intercept & -0.1571 & $\begin{array}{l}-2.9862 \\
\end{array}$ & 0.9321 & -0.0339 & -2.9862 & 0.9465 \\
\hline & $\begin{array}{l}\text { Intercept and } \\
\text { constant }\end{array}$ & -3.3305 & -3.6121 & 0.0853 & -3.2203 & -3.6032 & 0.1032 \\
\hline
\end{tabular}

Source: Authors' compilation and values from E-views 10. 
At levels, under both the ADF and PP unit root tests, all the variables are found to be non-stationary as indicated in Table 2 . This is because all the p-values for both tests are greater than 0.05 . Also, all the absolute t-statistics under all determinist terms are less than the t-critical values. The study further tested the stationarity of the variables at first difference under both ADF and PP. As indicated in Table 3, at $5 \%$ level of significance, the variables become stationary at first difference with an intercept as well as with an intercept and constant in the ADF unit root test. This is indicated by the absolute t-statistic for all variables under both tests being greater that the critical values at $5 \%$ level of significance at all deterministic terms. Also, the probability values for the ADF and PP tests are all below 0.05 , which led the researcher to reject the null hypothesis that the series for all variables contain a unit root. The tests further indicate that all the variables under investigation are all integrated of order one $\mathrm{I}(1)$.

TABLE 3

Unit root test results at first differencing- $A D F$ and $P P$

\begin{tabular}{|c|c|c|c|c|c|c|c|}
\hline \multirow{2}{*}{$\begin{array}{l}\text { Vari- } \\
\text { ables }\end{array}$} & \multirow{2}{*}{$\begin{array}{l}\text { Determinis- } \\
\text { tic terms }\end{array}$} & \multicolumn{3}{|c|}{ ADF-1 ${ }^{\text {st }}$ differencing } & \multicolumn{3}{|c|}{ PP $-1^{\text {st }}$ differencing } \\
\hline & & $\begin{array}{l}\text { t-statis- } \\
\text { tic }\end{array}$ & $\begin{array}{c}\text { t-critical } \\
\text { values } \\
5 \%\end{array}$ & P-values & $\begin{array}{l}\text { t-statis- } \\
\text { tic }\end{array}$ & $\begin{array}{c}\text { t- criti- } \\
\text { cal val- } \\
\text { ues } \\
5 \%\end{array}$ & P-values \\
\hline \multirow[b]{2}{*}{$\triangle \mathrm{LNPD}$} & Intercept & -4.4966 & -2.9918 & 0.0017 & -4.4975 & -2.9919 & 0.0017 \\
\hline & $\begin{array}{l}\text { Intercept and } \\
\text { constant }\end{array}$ & -4.5261 & -3.6121 & 0.0075 & -4.5417 & -3.6122 & 0.0073 \\
\hline \multirow{2}{*}{$\begin{array}{l}\Delta \text { LNG- } \\
\text { VTEX }\end{array}$} & Intercept & $\begin{array}{l}-5.5386 \\
\end{array}$ & -2.9918 & 0.0001 & -5.5386 & -2.9919 & 0.0001 \\
\hline & $\begin{array}{l}\text { Intercept and } \\
\text { constant }\end{array}$ & -5.6049 & -3.6121 & 0.0007 & -5.8084 & -3.6122 & 0.0004 \\
\hline \multirow[b]{2}{*}{$\begin{array}{l}\Delta \mathrm{LNG}- \\
\text { VTRV }\end{array}$} & Intercept & $\begin{array}{l}-5.1795 \\
\end{array}$ & -2.9918 & 0.0003 & -5.3697 & -2.9919 & 0.0002 \\
\hline & $\begin{array}{l}\text { Intercept and } \\
\text { constant }\end{array}$ & -5.1161 & -3.6121 & 0.0021 & -5.3521 & -3.6122 & 0.0012 \\
\hline
\end{tabular}

Source: Authors' compilation and values from E-views 10.

\subsection{COINTEGRATION TEST}

\subsubsection{THE JOHANSEN COINTEGRATION TEST}

Based on the existence of unit root, the cointegration property, is examined using both the Johansen and Engle and Granger cointegration tests. After establishing the series optimal lag length from the AIC as 2 as indicated by Table 4, the results of the Johansen cointegration trace and maximum eigenvalue tests are shown in Table 5. The null hypothesis of no cointegration is tested against the alternative that the variables are cointegrated. In Table 5, it is notable that the Johansen cointegration test supports the cointegration property. This implies that the public debt, government expenditure and government revenue are associated and move together in the long run during the period under review. 
TABLE 4

Lag length selection criteria

\begin{tabular}{|c|c|c|c|c|c|c|}
\hline Lag & $\log L$ & LR & FPE & AIC & SC & HQ \\
\hline 0 & -10.8620 & NA & 0.0006 & 1.1551 & 1.3024 & 1.1942 \\
\hline 1 & 85.0330 & $159.8252 *$ & $4.61 \mathrm{e}-07$ & -6.0860 & $-5.4970 *$ & $-5.9298 *$ \\
\hline 2 & 94.5717 & 13.5131 & $4.60 \mathrm{e}-07^{*}$ & $-6.1309 *$ & -5.1001 & -5.8575 \\
\hline
\end{tabular}

*Indicates the lag order selected by criterion, AIC.

Source: Authors.

\section{TABLE 5}

Johansen cointegration tests- Trace and Maximum eigenvalue

Unrestricted cointegration rank test (Trace \& maximum eigenvalue)

\begin{tabular}{|c|c|c|c|c|c|c|c|}
\hline $\begin{array}{l}\text { Hypoth- } \\
\text { esised no. } \\
\text { of CE(s) }\end{array}$ & $\begin{array}{l}\text { Eigen- } \\
\text { value }\end{array}$ & $\begin{array}{c}\text { Trace } \\
\text { statistics }\end{array}$ & $\begin{array}{c}0.05 \\
\text { Critical } \\
\text { value }\end{array}$ & P-value & $\begin{array}{c}\text { Max- } \\
\text { eigen } \\
\text { statistic }\end{array}$ & $\begin{array}{c}0.05 \\
\text { Critical } \\
\text { value }\end{array}$ & P-value \\
\hline None * & 0.8274 & 52.5909 & 29.7970 & 0.0000 & 40.4171 & 21.1316 & 0.0000 \\
\hline At most 1 & 0.3302 & 12.1737 & 15.4947 & 0.1488 & 9.2196 & 14.2646 & 0.2683 \\
\hline At most 2 & 0.1205 & 2.9540 & 3.8414 & 0.0857 & 2.9540 & 3.8414 & 0.0857 \\
\hline
\end{tabular}

Trace and Max-eigenvalue tests indicates 1 cointegrating eqn(s) at the 0.05 level

* denotes rejection of the hypothesis at the 0.05 level

Source: Authors.

\subsubsection{ENGLE AND GRANGER COINTEGRATION TEST}

The Engle and Granger cointegration approach requires an OLS regression between government expenditure as the dependent variable, and public debt and government revenue as independent variables to obtain the residual value. Residuals obtained from the model of GVTEX, PD and GVTRV log values were tested for the unit root using the ADF tests as indicated in Table 6. In Table 6, the study rejected the null hypotheses that the residual value $\left(U_{\mathrm{t}}\right)$ has a unit root. Given these cointegration tests results, the study employed the ECM to investigate both the short- and long-run dynamics among the variables.

TABLE 6

LnPD, LnGVTEX and LnGVTRV residuals unit root test result

\begin{tabular}{l} 
Augmented Dickey-Fuller test statistic \\
$\begin{array}{l}\text { Test } \\
\text { levels: }\end{array}-\frac{1}{\text { critical }}-\frac{\text { t-Statistic }}{-2.4355}-\frac{\text { Prob. }}{0.0171}$ \\
\hline
\end{tabular}

Source: Authors.

\subsection{ERROR CORRECTION MODEL}

Based on the cointegration property, the study estimated the ECM model. The coefficients LnPD and LnGVTRV are significant to explain LnGVTEX when the 
probability values are less than 0.05 . Most importantly, the sign of the ECT must be negative and significant to indicate a long-run equilibrium relationship. From the results in Table 7, the ECM indicates a statistically significant negative $\beta_{3}$ coefficient implying the existence of a long-run relationship and any shocks in the short run will be adjusted back to the long-run equilibrium by the ECT coefficient.

\section{TABLE 7}

ECM estimates (dependant variable: first differenced LnGVTEX)

\begin{tabular}{|c|c|c|c|c|}
\hline Variable & Coefficient & Std. Error & t-Statistic & Prob. \\
\hline $\mathrm{C}$ & 0.0547 & 0.0170 & 3.2204 & 0.0028 \\
\hline D(LNGVTRV)(-1) & 0.3657 & 0.1144 & 3.1949 & 0.0030 \\
\hline $\mathrm{D}(\mathrm{LNPD})(-1)$ & 0.1821 & 0.0372 & 4.8880 & 0.0000 \\
\hline $\mathrm{U}(-1)$ & -0.4643 & 0.1121 & -4.1383 & 0.0002 \\
\hline R-squared & 0.6140 & \multicolumn{2}{|c|}{ Mean dependent var } & 0.1382 \\
\hline Adjusted R-squared & 0.5800 & \multicolumn{2}{|c|}{ S.D. dependent var } & 0.0880 \\
\hline S.E. of regression & 0.0570 & \multicolumn{2}{|c|}{ Akaike info criterion } & -2.7903 \\
\hline Sum squared resid & 0.1106 & \multicolumn{2}{|c|}{ Schwarz criterion } & -2.6180 \\
\hline Log likelihood & 57.0175 & \multicolumn{2}{|c|}{ Hannan-Quinn criterion } & -2.7290 \\
\hline F-statistic & 18.0318 & \multicolumn{2}{|c|}{ Durbin-Watson stat } & 1.4024 \\
\hline Prob(F-statistic) & 0.0000 & & & \\
\hline
\end{tabular}

Source: Authors.

The speed of adjustment at which the ECT corrects the disequilibrium in the model or rather, the speed at which the system corrected its previous disequilibrium period due varied shocks is $46.43 \%$ annually. A positive significant relationship between government expenditure public debt and government revenue is also confirmed. However, in terms of the magnitude, government expenditure is more responsive to government revenue $(0.36 \%)$ when compared with public debt $(0.18 \%)$. This implies that, a 1 percent increase in government revenue will increase government expenditure by $0.36 \%$. Similarly, a 1 percent increase in government debt will increase government expenditure by $0.18 \%$. The positive relationship between government expenditure and revenue will force the government to run a budget deficit (increase tax rates) when revenues are insufficient to meet the increase in expenditures (to meet the increase in expenditures). Consequently, the country will be forced to resort to borrowing, thus increasing public debt. Additionally, the estimated model's R square (0.6140) is found to be less than the Durbin Watson statistics (1.725916) concluding the absence of spurious regression.

These findings are similar to those of Ukwueze (2015) and Okafor and Eiya (2011). These findings further support the positive theory of public expenditure for Peacock and Wiseman (1961) which states that government expenditure and taxes are positively related due to the displacement effect. Additionally, the findings are also in line with the Ricardian equivalence theory which states that both taxes and borrowings constitute essential equivalent forms of financing public expenditures. 
The study employed the pair-wise Granger causality test to test the direction of causality between public debts (LnPD), government expenditure (LnGVTEX) and government revenue (LnGVTRV). The study used 2 lags as the optimal lag length obtained by the criteria. The null hypothesis of no Granger causality is tested against the alternative of Granger causality between variables. The null hypothesis is rejected if the probability obtained is less than $5 \%(0.05)$ and fails to be rejected when the probability is greater than 0.05 .

\section{TABle 8}

Pair-wise Granger causality tests

\begin{tabular}{|c|c|c|}
\hline Null Hypothesis: & F-Statistic & Prob. \\
\hline LNGVTRV does not Granger Cause LNGVTEX & 4.1288 & 0.0254 \\
\hline LNGVTEX does not Granger Cause LNGVTRV & 1.2797 & 0.2920 \\
\hline LNPD does not Granger Cause LNGVTEX & 1.4328 & 0.2535 \\
\hline LNGVTEX does not Granger Cause LNPD & 8.9136 & 0.0008 \\
\hline
\end{tabular}

Source: Authors.

As reported in Table 8, a unidirectional causality was found running from government revenue to government expenditure as well as from government expenditure to public debt. This implies that government expenditure can be considered a useful tool to stimulate/contain public debt in Namibia. The findings are similar to those of Mah et al. (2013), Oladokun (2015) as well as Idnyi, Ogonna and Ifeyinwa (2016). The causality between government expenditure and government revenue was tested to serve in the devising of an optimal strategy to reduce the budget deficit and further reduce public debt. The results further support the revenue spend hypothesis theory of Friedman (1978) implying that government revenue causes government expenditure. This indicates that budget deficit could be eliminated through policy implementations that stimulate government revenue. The results are also consistent with those of Eita and Mbazima (2008) and Ogujiuba and Abraham (2012). However, the above results failed to support the Peacock and Wiseman (1961) hypothesis, which states that government expenditure causes government revenue, indicating that the spend-revenue hypothesis is absent in Namibia. Additionally, the above results are contrary to the findings of Saungweme (2013) who found causality running from government expenditure to revenue.

\subsection{DIAGNOSTIC TEST}

To ensure the robustness of the estimates, several diagnostic tests were performed. Table 9 shows that, the model satisfies the assumptions of no heteroscedasticity, no autocorrelation and normality. Similarly, the CUSUM that test on Figure 3 shows that the model is stable. 
TABLE 9

Diagnostic tests for heteroscedasticity, autocorrelation and normality

\begin{tabular}{|c|c|c|}
\hline Test & Null hypotheses & Probability \\
\hline Heteroscedasticity test: Breusch-Pagan-Godfrey & No heteroscedasticity & 0.9410 \\
\hline Breusch-Godfrey serial correlation LM Test & No autocorrelation & 0.7152 \\
\hline Histogram normality test & There is normality & 0.5467 \\
\hline
\end{tabular}

Source: Authors.

Figure 3

CUSMUS stability test

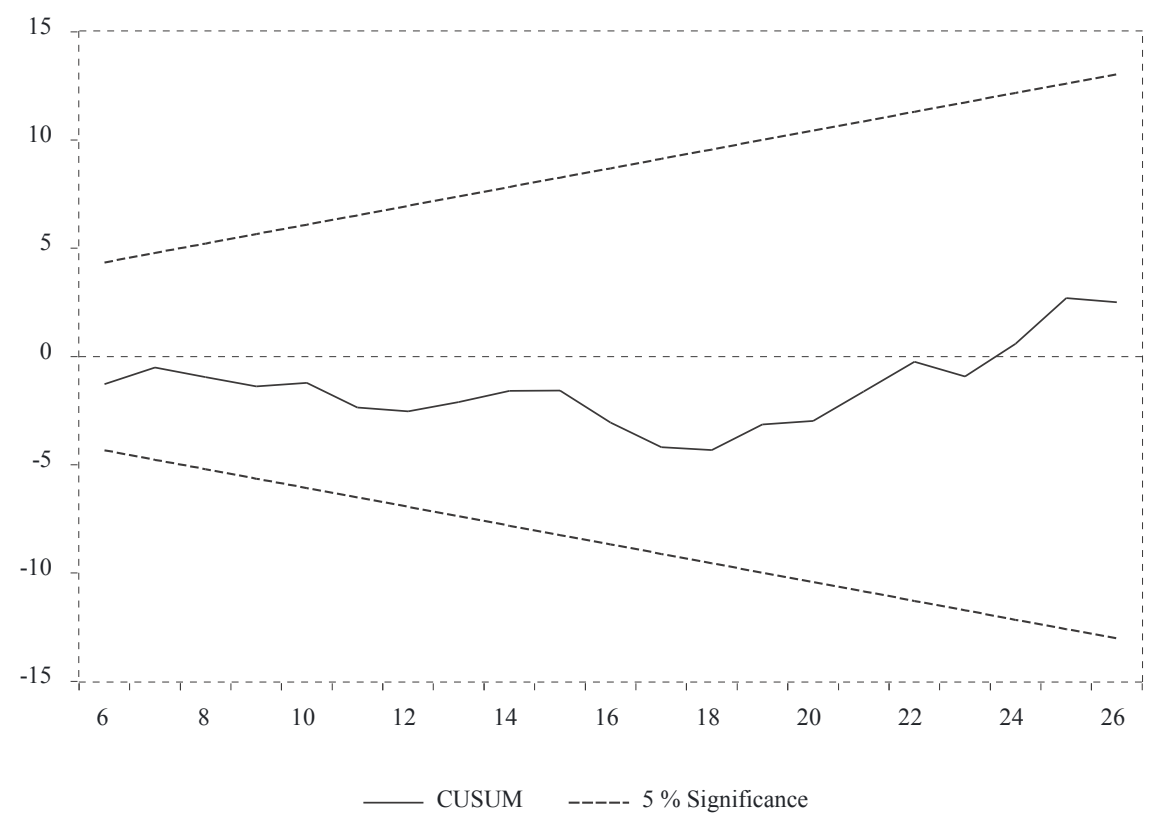

Source: Authors.

\section{CONCLUSIONS AND RECCOMENDATIONS}

This paper aimed to address both the literature gap and policy-makers' concerns about fiscal sustainability by investigating the relationship between the dynamics of government expenditure, revenue and public debt. The cointegration results indicated long-run relations between government expenditure, government revenue and public debt. The ECM model revealed a positive and significant relationship between government expenditure, government revenue and public debt. In addition, the ECT from the study was negative and statistically significant confirming that all previous disequilibrium in the three variables is removed in the following period and is adjusted back to the long-run equilibrium at an average speed of slightly over $46 \%$ annually. Therefore, the study confirms the existence of positive long-run relationships between government expenditure, public debt government revenue. The Granger causality testing confirmed the existence of a unidirectional causality from government expenditure to public debt. Similarly a unidirectional 
causality from government revenue to government expenditure is supported. This implies that the past values of government expenditure can help predict the government debts, but public debt is not a useful tool in determining government expenditure. Such a relationship indicates that policy-makers have the ability to control the country's borrowings through government spending. The existence of the unidirectional causality from government revenue to government expenditure provides evidence that the tax-spend hypothesis is borne out in Namibia as increasing taxes lead to more government spending. There is robust evidence that the Namibian government can efficiently use fiscal variables to achieve fiscal sustainability. The study recommends policy-makers to thoroughly review fiscal policy by efficiently adopting the functional finance as suggested by the Lerner theory. This involves judging all fiscal measures according to their functions in the economy. Fiscal imbalances can also be eliminated through implementation of long-term policies that stimulate government revenue, while still attempting to mitigate their expenditures to stabilise borrowings in the short run.

The study further advises policy-makers to avoid overstating revenue and understating expenditure estimates from the inception of the budget process and to learn the art of spending within their means. Lastly, borrowed funds should be productively spent on successful capital expenditures/projects. Conversely, this might serve as a challenge to Namibia since the biggest portion of its expenditure is operational, particularly related to the administration. An expansion on the variables is suggested for further research. Since the study found unidirectional causality from government expenditure to public debt, future research, to investigate the relationship between public debt and individual operational and development expenditures is recommended in order to determine the discrete impact that expenditure has on borrowing. Finally, further research is suggested in order to improve the data once they become available.

\section{Disclosure statement}

No potential conflict of interest was reported by the authors. 
1. Adams, R. J., Weiss, T. D. and Coatie, J. J., 2010. The World Health Organisation, its history and impact. London: Perseus.

2. Alawneh, A., 2017. The impact of public expenditure and public debt on taxes: A case study of Jordan. Accounting and Finance Research, 6(3), pp. 10-23. https://doi.org/10.5430/afr.v6n3p10

3. Abdulrasheed, B., 2017. Causality between government expenditure and revenue in Nigeria. Asian Journal of Economics and Empirical Research, 4(2), pp. 91-98. https://doi.org/10.20448/journal.501.2017.42.91.98

4. Achieng, W. J., 2012. The relationship between government budget deficit and domestic debt in Kenya. Master's Thesis. Nairobi: University of Nairobi.

5. Balassone, F. and Franco, D., 2000. Assessing fiscal sustainability: A review of methods with a view to EMU. Proceedings to the Bank of Italy Public Finance Workshop on Fiscal Sustainability, pp. 21-60. https://doi.org/10.2139/ ssrn.2109377

6. Barro, R. J., 1974. Are government bonds net wealth? Journal of Political Economy, 82(6), pp. 1095-1117. https://doi.org/10.1086/260266

7. Barro, R. J., 1979. On the determination of the public debt. Journal of Political Economy, 87(5), pp. 940-971.

8. Buchanan, J. M. and Wagner, R. W., 1977. Democracy in deficit. New York: Academic Press.

9. Cottarelli, C. and Schaechter, A., 2010. Long term trends in public finances in the G-7 economies. IMF Staff Position note, SPN/10/13.

10. Eita, J. H. and Mbazima, D., 2008. The causal relationship between government revenue and expenditure in Namibia. Journal of Economic and Financial Sciences, 2(2), pp. 175-186. https://doi.org/10.4102/jef.v2i2.353

11. Elyasi, Y., and Rahimi, M., 2012. The Causality between government revenue and government expenditure in Iran. International Journal of Economic Sciences and Applied Research, 5(1), pp. 129-145. https://doi.org/10.2139/ ssrn. 1977987

12. Engle, R. F. and Granger, C. W., 1987. Cointegration and error correction: Representation, estimation and testing. Econometrics, 55(14), pp. 251-276.

13. Friedman, M., 1978. The Limitations of Tax Limitations. Policy Review, (5), pp. 7-14.

14. Favero, C. and Giavazzi, F., 2007. Debt and the effects of fiscal policy. NBER Working paper, No. 12822.

15. Granger, C. W. J., 1969. Investigating causal relations by econometric models and cross-pectral methods. Econometrica, 37(3), pp. 424-438. https://doi. org/10.2307/1912791

16. Gujarati, D., 2004. Basic econometrics. London: McGraw Hill.

17. Idenyi, O. S., Ogonna, I. C. and Ifeyinwa, A. C., 2016. Public debt and public expenditure in Nigeria: A causality analysis. Research Journal of Finance and Accounting, 7(10), pp. 27-38. 
18. Ighodaro, C. A. and Oriakhi, D. E., 2010. Does the relationship between government expenditure and economic growth follow Wagner ${ }^{\text {ee }} \mathrm{s}$ law in Nigeria. Annals of University of Petrosani Economics, 10(2), pp. 185-198.

19. Kanano, A. G., 2006. Determinants of public expenditure growth in Kenya. Master's Thesis. Nairobi: University of Nairobi.

20. Keynes, J. M., 1936. The general theory of employment, interest and money. New York: Cambridge University Press.

21. Kiminyei, F. K., 2014. Public debt, tax revenue and government expenditure in Kenya: 1960- 2012. Master of Economics Thesis. Nairobi: University of Nairobi.

22. Labonte, M., 2012. Reducing the budget deficit: Policy issues. Congressional research service report for progress.

23. Lerner, A. P., 1943. Functional finance and the federal debt. Social Research, 10(1), pp. 38-51.

24. Luković, S. and Grbić, M., 2014. The causal relationship between government revenue and expenditure in Serbia. Economic themes, 52(2), pp. 127-138. https://doi.org/10.1515/ethemes-2014-0009

25. Mah, G. [et al.], 2013. The impact of government expenditure on the Greek government debt: An econometric analysis. Mediterranean Journal of Social Sciences, 4(3), pp. 323-330. https://doi.org/10.5901/mjss.2013.v4n3p323

26. Mill, J. S., 1979. Principles of Political Economy. Fairfield: Augustus M. Kelley.

27. Ministry of Finance, 2005. Sovereign debt management strategy. Windhoek.

28. Ministry of Finance, 2017. Fiscal strategy for the 2017/18- 2019/20 MTEF. Windhoek.

29. Neck, R. and Sturm, J., 2008. Sustainability of public debt. London: The MIT Press : Cambridge.

30. Ogujiuba, K. and Abraham, T. W., 2012. Testing the relationship between government revenue and expenditure: Evidence from Nigeria. International Journal of Economics and Finance, 4(11), pp. 172-182. https://doi.org/10.5539/ ijef.v4n11p172

31. Okafor, C. and Eiya, O., 2011. Determinants of growth in government expenditure: An empirical analysis of Nigeria. Research Journal of Business Management, 5(1), pp. 44-50. https://doi.org/10.3923/rjbm.2011.44.50

32. Oladokun, O. O., 2015. Causal relationship between public debts and public expenditure in Nigeria. International Journal of Management and Applied Science, 1(8), pp. 68-79.

33. Peacock, A. T. and Wiseman, J., 1961. The growth of public expenditure in the United Kingdom. London: Oxford University Press.

34. Presbitero, A. F., 2010. Total public debt and growth in developing countries. Development Studies Working Paper, No. 300.

35. Ray, S., 2012. Testing granger causal relationship between macroeconomic variables and stock price behaviour: evidence from India. Advances in Applied Economics and Finance, 3(1), pp. 470-481. 
36. Saungweme, T., 2013. Causality between government expenditures and revenues: The Zimbabwean case 1980-2004. International Journal of Economic Research, 4(6), pp. 28-40.

37. Schick, A., 2005. Sustainable Budget Policy: Concepts and approaches. OECD Journal on Budgeting, 5(1), pp. 107-126.

38. Sherbourne, R., Nampila, T. and du Preez, R., 2002. Maintaining economic independence: government debt and fiscal sustainability. IPPR Briefing Paper, No. 13.

39. Smith, A., 1937. The Wealth of Nations. New York: Random House.

40. Sutherland, A., 1997. Fiscal crises and aggregate demand: can high public debt reverse the effects of fiscal policy?. Journal of public economics, 65(2), pp. 147-162. https://doi.org/10.1016/s0047-2727(97)00027-3

41. Uguru, L. C., 2016. The link between public debt and government expenditure pattern: The Nigeria experience. Journal of Business and Management, 18(1), pp. 37-41.

42. Ukwueze, E. R., 2015. Determinants of the size of public expenditure in Nigeria. SAGE Open, pp. 1-8. https://doi.org/10.1177/2158244015621346

43. Zaaruka, B. B., Ndove, T. and Tjipe, T., 2004. Central government debt sustainability. Bank of Namibia Working Paper Series, 8/4/2/WP 1/2004. 